\title{
Izabela Huber
}

Mileševska 3, RS-11000 Beograd

izabelahuber@gmx.at

\section{Fenomenologija tijela i tjelesne psihoterapije}

\begin{abstract}
Sažetak
Nakon što su Nietzsche i Klages pripremili teren za to da tijelo, shvaćeno drugačije nego u okviru kartezijanske postavke i prirodnih znanosti, postane predmet filozofskog istraživanja, Schmitz je razvio prvi sistematski fenomenološki pristup tijelu. Polazi od jedne radikalne i dosljedne fenomenološke definicije tijela (Leib nasuprot Körper) te razvija teorijski okvir $i$ vokabular koji omogućava govor o čitavom rasponu stanja koja se doživljavaju tijelom. U psihoterapiji, tijelo je tematizirano najprije u ranim tjelesnim psihoterapijama koje su imale korijen u psihoanalizi (Reich, Lowen, Kelley). U njima prevladava shvaćanje tijela kao fizičkog tijela (Körper). Čisto fenomenološki pristup tijelu u psihoterapiji (u smislu Schmitzova Leib) razvio je Gendlin. Suvremene tjelesno orijentirane psihoterapije (Levine, Ogden, van der Kolk) razvile su se naročito u terapiji posttraumatskog sindroma $i$ integriraju fenomenološki rad s tijelom s kognitivno-narativnim postupcima i novim neurobiološkim spoznajama. I fenomenologija tijela i tjelesne psihoterapije, svaka na svoj način, nastoje balansirati hipertrofiju racionalnog, kognitivnog $i$ duhovnog u kulturi, pomičući fokus na područje tjelesnosti, na neopredmećene, fluidne, teško izrecive dijelove iskustva koji su stoljećima marginalizirani u filozofiji i znanosti unatoč tomu što igraju značajnu ulogu u svijetu života (Lebenswelt).
\end{abstract}

\section{Ključne riječi}

fenomenologija, tijelo, tjelesne psihoterapije, Hermann Schmitz, Friedrich Nietzsche, Ludwig Klages

Duša je bila privlačna i tajanstvena misao od koje su se filozofi s pravom nevoljno odvojili. Ali ono čime sada uče zamijeniti je možda je još privlačnije i još tajanstvenije. Ljudsko tijelo, na kojemu čitava najudaljenija i najbliža prošlost svog organskog postajanja ponovo oživljava i otjelovljuje se, kroz koje i iz koga izgleda da teče jedna golema, nečujna struja: tijelo je u većoj mjeri zapanjujuća misao od stare duše. ${ }^{1}$

Friedrich Nietzsche

Možda su Nietzscheov patetični okršaj s kršćanstvom kao metafizikom i formom života, kao i duboki skepticizam prema moći jezika da opiše »metafizičku« istinu koja bi postojala izvan samog jezika, bili neophodni koraci da

Friedrich Nietzsche, Nachgelassene Fragmente 1885, u: Friedrich Nietzsche, Friedrich Nietzsche Digitale Kritische Gesamtausgabe Werke und Briefe (eKGWB), Paolo D'Iorio (ur.), Nietzsche Source, 2009., fr. 36[35] Dostupno na: http://www.nietzschesource. org/\#eKGWB/NF-1885,36[35] (pristupljeno 10. 9. 2017.). 
bi tijelo postalo predmetom filozofije. Na najevidentnijoj razini Nietzscheova pristupa tijelu, nalazimo kritiku kršćanskog prezira prema tijelu i shvaćanja askeze koje je neprijateljsko prema životu. Nasuprot tomu, Nietzsche uzdiže tijelo i tjelesnost i pita se:

»Ima li opasnije zablude od prezira prema tijelu? Nije li time čitava duhovnost osuđena na to da postane bolesna? $\ll^{2}$

U pokušaju da rekonstruira i u sadašnjosti oživi jedan pretkršćanski doživljaj stvarnosti, Nietzsche se vraća grčkoj, naročito predsokratovskoj kulturi. U njoj su dva suprotna principa - apolonsko (racionalnost, poredak, mjera) i dionizijsko (razuzdanost, čulnost, ekstaza) dosegli rijetku točku ravnoteže koja je, prema Nietzscheu, narušena već od Sokrata, a potpuno izgubljena pojavom kršćanstva. Od tada u europskoj kulturi, filozofiji i religiji središnju ulogu igraju duh, forma i racionalnost, dok im nedostaju energija i vitalnost. Nietzsche ovoj tendenciji suprotstavlja sliku plešućeg boga Dioniza i u dionizijskom ritualu inkarniranog božanstva traži lijek za sterilnost i beživotnost koju je na Zapadu stvorila dominacija apolonskog principa. Međutim, Nietzsche ide korak dalje od pledoajea za jedan životni stil koji afirmira tjelesnost; on svojom intuicijom velikog uma tijela (die große Vernunft des Leibes), tijelu kao totalitetu postojanja (čiji je duh samo sastavni dio) daje primat, kako u ontološkom, tako i u metodološkom smislu. Za Nietzschea, tjelesnost (Leiblichkeit) je temeljni fenomen postojanja, nadređen duhu i svakomu svjesnom mišljenju, osjećanju i htijenju; tijelo je, u metodološkom smislu također, kao bogatiji, jasniji i razumljiviji fenomen pretpostavljen duhu. Kako je tijelo bogatiji fenomen, a vjerovanje u tijelo bolje utemeljeno od vjere u duh, tijelo mora poslužiti kao glavna nit vodilja (Leitfaden) u proučavanju čovjeka. ${ }^{3}$ Pri tome, Nietzsche misli ne samo na tijelo kao fizički objekt, na stvar (Körper), odnosno tijelo u anatomskom smislu, nego možda prije svega na tijelo u smislu doživljajnog tijela (Leib), onoga što će kasnije postati predmet fenomenologije tjelesnosti. Nietzsche se tako ne suprotstavlja samo religiozno utemeljenom neprijateljstvu prema tijelu nego i prirodoznanstveno-medicinsko-fizikalističkom konceptu tijela.

»Koliko je različito tijelo onako kako ga doživljavamo, vidimo, osjećamo, kako ga se bojimo, divimo mu se, od onoga što nas anatomi podučavaju! ${ }^{4}$

Nietzscheove lajtmotive na svoj način slijedi Ludwig Klages, u čijem se djelu može vidjeti i anticipacija Schmitzove nove fenomenologije. Klagesov konzekventno biocentrični pogled na svijet, čak biocentrična metafizika (prema njegovim riječima radi se o »metafizici poganstva«), sadrže u sebi kritiku monoteizma, trendova u filozofiji i psihologiji Klagesova vremena, kao i kritiku civilizacije koja pod imenom tehnološkog progresa progresivno otuđuje čovjeka od prirode i prijeti uništiti život na planeti. Klages je sjeme ovog kobnog, devastirajućeg procesa vidio u samim počecima povijesti. Duboko svjestan da nalikuje Kasandri, na čija se upozoravajuća proročanstva nitko ne obazire, Klages svojim učenjem o hibrisu duha i sumraku duše ostaje i danas aktualan, čak na način akutniji, nego u svoje vrijeme.

Problem odnosa tijela prema duši i duhu Klages je tematizirao u više radova, od poetičnog O kozmogonijskom Erosu (1922.) do obimnog, sistematskog djela rječitog naslova Duh kao protivnik duše (1929.-1932.). Umjesto kartezijanskog dvojstva (tijelo-duh), Klages se vraća antičkom trojstvu tijelo-duša-duh, dajući pojmovima novo značenje. Tijelo i duša nedjeljiva su cjelina. 
»Kozmos živi i sav život polariziran je na dušu (psyche) i tijelo (soma). Gdje god je živo tijelo, tu je i duša; gdje god je duša, tu je i živo tijelo. Duša je smisao tijela, slika tijela je pojavljivanje duše. Što god se pojavljuje ima smisao i svaki smisao očituje se u tomu u čemu se što pojavljuje. Smisao se doživljava iznutra, pojava izvana. $\ll^{5}$

Polaritet (ali ne i dualitet!) duše i tijela sačinjava doživljajnu i ekspresivnu stvarnost života, a njihovim razdvajanjem, ona se urušava. Duh (logos, pneuma, nus), prema Klagesu, ona je antagonistička moć koja postoji samo kod čovjeka, koja je van prostora i vremena, koja rastavlja polove i time ih poništava, tijelo lišava oduševljenja (entseelen) i dušu otjelovljenja (entleiben). Vladavinu duše kod pretpovijesnog čovjeka zamjenjuje vladavina duha kod povijesnog čovjeka. Duh čine pojmovno, racionalno mišljenje i volja. Pojmovno mišljenje izolira svoje predmete iz doživljajne, fenomenalne stvarnosti, čime utvrđuje identitet i diskontinuitet predmeta mišljenja, udaljavajući se time sve više od doživljajnog toka i cjelovitosti pojavnosti. ${ }^{6}$ Drugi aspekt duha, volja, prije nego intelekt, ono je što Klages zapravo vidi kao potencijalnu prijetnju životu. Volja koja se osamostaljuje od vitalnih nagona i želja i slijedi zamišljene ciljeve $\mathrm{i}$ interese, potencijalno postaje antagonistom života. Tako volja i mišljenje, koje je kroz povijest sve više prelazilo iz službe životu u službu volje, teže ovladavanju prirodom, tijelom i osjećajnim životom i njihovoj potpunoj regulaciji i kontroli. Emancipiran od života, duh postaje prijetnja čovječanstvu.

Duh i život susreću se u svojem zajedničkom uporištu, koje je postalo središtem čovjekovog života, a to je ja (Ich), odnosno sebstvo (Selbst). Fenomenalna stvarnost i duša-tijelo postoje u vremenu; ja je vanvremenski identitet, odvojen od stalnog tijeka promjene. Samo kroz mišljenje i volju, čiji je sebstvo nosilac, razabiremo glasove svega od čega smo razdvojeni. Jedino u stanju ekstaze dolazi do oslobođenja. Klages smatra da ono što se oslobađa u ekstazi nije duh, nego duša i ona se ne oslobađa od tijela, nego upravo od duha i posljedično, od sebstva. U kulturi u kojoj vlada duh, koji se osamostalio od života, sve iracionalno, emocionalno, ekstatičko, kontemplativno biva

Friedrich Nietzsche, Nachgelassene Fragmente 1888, u: F. Nietzsche, Friedrich Nietzsche Digitale Kritische Gesamtausgabe Werke und Briefe (eKGWB), Paolo D'Iorio (ur.), Nietzsche Source, 2009., fr. 14[37]. Dostupno na: http://www.nietzschesource.org/\#eKGWB/ NF-1888,14[37] (pristupljeno 10. 9. 2017.)

3

Friedrich Nietzsche, Nachgelassene Fragmente 1886, u: F. Nietzsche, Friedrich Nietzsche Digitale Kritische Gesamtausgabe Werke und Briefe (eKGWB), Paolo D'Iorio (ur.), Nietzsche Source, 2009., fr. 5[56]. Dostupno na: http://www.nietzschesource.org/\#eKGWB/ NF-1886,5[56] (pristupljeno 10. 9. 2017.); F. Nietzsche, Nachgelassene Fragmente 1885, fr. 40[15]. Dostupno na: www.nietzschesource.org/\#eKGWB/NF-1885,40[15] (pristupljeno 10. 9. 2017.).

F. Nietzsche, Nachgelassene Fragmente 1881, fr. 14[2]. Dostupno na http://www.nietzschesource.org/\#eKGWB/NF-1881,14[2] (pristupljeno 10. 9. 2017.)
Ludwig Klages, Vom kosmogonischen Eros, Georg Müller Verlag, München 1922., str. 43.

Primijetimo da prirodoznanstvena rekonstrukcija pojma $d u h$, koju u svojim istraživanjima uspješno provode suvremena kognitivna znanost i filozofija duha kao njena meta-teorijska nadgradnja, polazi upravo od ovakvog koncepta duha (koji je puno bliži tradicionalnom značenju engleskog mind, nego njemačkog Geist). Reprezentacijski sadržaji i mentalne operacije mogu se prilično uspješno opisati komputacijskim jezikom, ali ono što se posljednjih desetljeća pokazalo kao tvrdokorni problem ove paradigme danas je u filozofiji duha poznato kao problem qualia, tj. problem fenomenalne svijesti. Fenomenalna svijest, slično onome što je Klages mislio pod pojavnošću, ostaje netaknuta eksplanatornim paradigmama kognitivne znanosti; one su, naime, kompatibilne i s njenim odsustvom. 
marginalizirano i viđeno kao sumnjivo. Klages se bavi ovim fenomenima, označavajući svoju znanost kao znanost o pojavnosti (Erscheinungswissenschaft), za razliku od znanosti o činjenicama, stvarima i njihovim kauzalnim odnosima (Sachwissenschaft). ${ }^{7}$

Tek u novoj fenomenologiji Hermanna Schmitza, pristup tjelesnosti dobiva sistematski konceptualni okvir koji omogućava govor o aspektima iskustva koji su marginalizirani, čak gotovo eliminirani, kako u filozofskom, tako i u teološkom i znanstvenom diskursu. Time je otvoren novi prostor za istraživanje neposrednog, otjelovljenog iskustva svijeta u filozofiji, kao i za njen dijalog s nizom disciplina (medicina, psihoterapija, etika, estetika, teologija) koje su u praksi nužno upućene na ovaj predmet, ali im je većinom nedostajao teorijski okvir koji bi dao integritet tematizaciji subjektivnosti, bez uvođenja robusnih metafizičkih pretpostavki. Tako je, primjera radi, psihoterapija prečesto maskirala pseudo-objektivističkom terminologijom, pa čak i fizikalističkim modelima sumnjive heurističke i pragmatičke vrijednosti, subjektivno porijeklo činjenica na kojima je gradila teorije (subjektivno u smislu činjenica prvog lica, koje ustanovljuje osoba koja ih neposredno doživljava).

Da bi razvio novi fenomenološki pojam tjelesnosti i doživljavanja tijelom, Schmitz se najprije mora razračunati s dogmama klasične teorije spoznaje i antropologije, koje bi ovakav njegov predmet svrstale u domenu privatnog, unutrašnjeg ili duševnog. Tri implicitne, međusobno povezane i gotovo nikada preispitane pretpostavke, obilježile su grčku misao od 5. stoljeća p.n.e., te potom i svu zapadnu filozofiju, teologiju i nauku - smatra Schmitz i označava ih kao introjekcionizam, redukcionizam i psihologizam. ${ }^{8}$ Svim aspektima iskustva koji se na izvjestan način mogu opredmetiti (vergegenständlichen) biva priznato objektivno postojanje, dok ostatak životnog iskustva, koji često čine najvažniji aspekti čovjekovog postojanja (kao npr. tjelesna stanja, utisci, osjećaji, prostornost, atmosfere, situacije), biva sklonjen u subjektivne unutrašnje svjetove, gdje ispod praga verbalizacije i pojmovnog osvješćenja, gubi vremenom svaku vrijednost i pada u zaborav. Ovu tendenciju Schmitz naziva introjekcionizmom (od introjektirati tj. pounutriti) i ona je povezana $\mathrm{s}$ redukcionizmom - svođenjem empirijskog svijeta na ograničen broj odlika, koje se intermomentano i intersubjektivno mogu lako identificirati i koje se danas mogu istraživati statističkim i eksperimentalnim metodama znanosti. Ono što pri tome preostane kao nemjerljivo i nereducibilno biva pounutreno u pretpostavljeni zatvoreni unutrašnji svijet doživljavanja - dušu kao utočište subjektivnosti. Hipotezu o postojanju jedinstvenog zatvorenog, unutrašnjeg svijeta, kojemu pripadaju svi doživljaji jednog čovjeka i kojim vlada neka centralna instanca, poput volje ili razuma, Schmitz označava kao psihologizam. Smještanje nevoljnih doživljaja poput tjelesnih osjeta i osjećanja u privatni unutrašnji svijet nastalo je, pored toga, iz potrebe da se nad njima uspostavi kontrola; pojam duše odlikuje dvojstvo značenja - duša je istovremeno subjekt i prostor doživljavanja, gospodar u kući i sama kuća. Vjerovanje u jedinstvenu dušu (ponekad duh, u novije vrijeme svijest, koje Schmitz smatra surogatima duše) koja, poput kontejnera, sadrži misli, opažaje, osjećanja, predstave, nagone, namjere i sl. veoma je rašireno i kroz povijest filozofije u pitanje su ga dovodili uglavnom materijalisti. Danas, u aktualnoj formi eliminativnog materijalizma (Paul Churchland, Patricia Churchland, Daniel Dennett, Georges Rey), tvrdi se da je ne samo koncept duše nego i naše zdravorazumsko shvaćanje mentalnih stanja pogrešno i da se veliki broj psiholoških pojmova ne odnosi ni na šta postojeće te se bez štete može eliminirati. Samo jedan dio psiholoških pojmova bit će zamijenjen preciznijim neurobiološkim određenjima te će, iz tog razloga, također postati izlišan. U ekstremnoj formi 
suvremenog neurobiološkog imperijalizma, valjanost psiholoških koncepata biva procjenjivana njihovom reducibilnošću na moždane procese!

Kada Schmitz, međutim, tvrdi da duša nije nešto što se može pronaći, nego je ideološki konstrukt koji potječe od Grka iz vremena oko 5. stoljeća p.n.e., koji je kod Platona bio već u punom procvatu, on cilja u sasvim drugom pravcu od ove danas popularne forme materijalizma. Posljedica psihologizma rascjep je na izvanjski i unutrašnji svijet; tijelo koje se pojavljuje kao predmet filozofije i znanosti uglavnom je shvaćeno kao fizičko tijelo koje se može vidjeti i opipati, dok je doživljaj vlastite tjelesnosti, kao nešto o čemu se jedva može govoriti, smješteno u tamni ugao duše, asylum ignorantiae, gdje se zlopati u zaboravu. Schmitzu je stalo do toga da otvori prostor za govor o nevoljnim doživljajima, o čitavom rasponu stanja koja doživljava tijelo, a koja se ne mogu opaziti uz pomoć pet čula. To su, na primjer, tjelesni osjećaji u užem smislu (bol, glad, žeđ, svrab, gađenje, prijatnost, umor, svježina), atmosfere u smislu klimatskih prilika koje se opažaju tijelom i u smislu osjećanja u kojima je tijelo afektivno pogođeno (radost, tuga, čežnja, ljubav, mržnja, strah), tjelesni doživljaj pokreta (drhtanje, žvakanje, gutanje, hodanje, plesanje), pravaca, prostora, situacija i tjelesne komunikacije.

Schmitz je koristio pogodnost njemačkog jezika, koji ima dvije riječi za tijelo - Körper i Leib - da bi izveo preciznu pojmovnu distinkciju između njih i time postavio osnovu za fenomenološko istraživanje tjelesnosti, čiji je predmet doživljajno tijelo Leib, dakle sasvim drugačiji od onoga čime se bave prirodne nauke (Körper) iz svog fizikalističko-redukcionističkog referentnog okvira. ${ }^{9}$ U osnovi, Schmitz polazi od diferencijacije onoga što osjećamo tijelom i onoga što opažamo čulima. Za razliku od Körper koje možemo vidjeti i opipati, Leib je ono što netko u predjelu vlastitog fizičkog tijela (Körper) iz sebe samog može osjetiti bez upotrebe čulnih organa (pet čula) i perceptivne sheme tijela (koja je, na osnovu čula vida i dodira, naučena predstava o vlastitom tijelu). Tjelesni osjećaj može biti lociran i van granica vizualno i taktilno opaženog tijela, kao u slučaju fantomskog uda posle amputacije. To što osjećamo u predjelu vlastitog tijela (Leib) rasprostrto je, ali na drugačiji način od tijela koje opažamo čulom vida i dodira (Körper). Dok fizičko tijelo posjeduje oštru, površinsku granicu na koži, osjećajno tijelo ne posjeduje površine, ali posjeduje predimenzionalni, nedjeljivi volumen, slično kao što voda, kako se pojavljuje plivaču, ili zvuk kako ga čujemo, nemaju površinu, nego samo volumen. Tjelesno (leiblich), kako ga osjećamo nezavisno od

Ovdje su prepoznatljivi Nietzscheovi motivi. Nietzsche svoju filozofiju naziva čak »izokrenutim platonizmom« jer je njen cilj život u pojavnosti. Vidi: Friedrich Nietzsche, Nachgelassene Fragmente 1870, u: F. Nietzsche, Friedrich Nietzsche Digitale Kritische Gesamtausgabe Werke und Briefe (eKGWB), Paolo D'Iorio (ur.), Nietzsche Source, 2009. fr. 7[156]. Dostupno na: http://www.nietzschesource.org/\#eKGWB/NF-1870,7[156].

8

Vidi: Hermann Schmitz, Der unerschöpfliche Gegenstand, Bouvier Verlag, Bonn 1990., str. 16-24, 115-130, 199-201.

9

Niz autora pokušao je uz pomoć kovanica povuči ovu distinkciju u francuskom jeziku; spomenimo ovdje Sartreovo razlikovanje tijela za sebe i tijela za druge (corps pour soi i corps-pour-autrui), Merleau-Pontyjevo razlikovanje živog (fenomenalnog, funkcionalnog) tijela (corps vivant, corps phénoménal, corps fonctionnel) i objektivnog, fizičkog tijela (corps objectif, corps physical) i razlikovanje tijela koje imam i tijela koje jesam (corps que j'ai i corps que je suis), od čega polazi Gabriel Marcel. Način na koji ovi autori povlače razliku između dva značenja pojma tijelo nije identičan Schmitzovom i ne posjeduje njegovu radikalnost i konzekventnost. Pošto smo odlučili da u ovom radu slijedimo razvoj mišljenja o fenomenologiji tjelesnosti kod njemačkih filozofa, nećemo se na ovom mjestu dalje baviti uspoređenjima. 
perceptivne sheme tijela koja počiva na čulu vida i dodira, nalazi se uvijek na jednom apsolutnom mjestu, za razliku od fizičkog tijela (Körper), koje zauzima relativno mjesto koje se može identificirati samo preko pozicije i rastojanja u dimenzionalnom prostornom sistemu. Osjećajno tijelo obično ima strukturu manjeg ili većeg broja fluktuirajućih otoka koji većinom nisu jasno ocrtani i koji se mogu identificirati nezavisno od prostorne orijentacije, odnosno posjeduju apsolutno mjesto.

Schmitz nastoji razviti kategorijalni sistem, metaforički rečeno »alfabet« temeljnih odlika tjelesnih stanja pomoću kojega je moguće opisati svu raznolikost konkretnih tjelesnih iskustava. Osnovna dimenzija na kojoj se mogu smjestiti gotovo svi ${ }^{10}$ tjelesni doživljaji tendencija je sužavanja (Engung) i širenja (Weitung). U dinamici tjelesnog doživljavanja, ove se dvije tendencije neprestano smjenjuju, prisutne su u različitim stupnjevima i različitim međusobnim odnosima - dinamičke konkurencije (simultano ili sukcesivno) ili djelomične nezavisnosti. Tendencija sužavanja prevladava, na primjer, u stanjima straha, bola, gladi, napete koncentracije, tjeskobe; tendencija širenja u stanju duboke opuštenosti, radosti, lakoće, drijemanja, prilikom padanja u san. Schmitz osvjetljava kompleksnu dinamiku sužavanja i širenja kroz minuciozne opise različitih tjelesnih osjećaja i osjećanja. ${ }^{11}$

Psihoterapija, koja se posljednjih desetljeća konstituira kao znanstvena disciplina, jedan je od najznačajnijih prostora za praktičnu primjenu fenomenologije tjelesnosti. Za razliku od suvremene psihologije, u kojoj je prirodoznanstvena orijentacija odnijela apsolutnu prevagu, psihoterapija je, prirodnom predmeta i pragmatičkog pristupa, upućena na traženje svog novog mjesta između prirodoznanstvene i duhovno-znanstvene paradigme. U, posljednjeg desetljeća aktualnoj postavci, to prvenstveno znači između neuroznanosti i fenomenologije. Od kada je neuroznanost, zahvaljujući novim neurotehnologijama, počela proučavati kompleksne psihičke procese, fenomenologija je postala neophodan dio istraživačkog procesa; bez nje je često teško interpretirati snimke moždane aktivnosti. Psihoterapija i neurobiologija stupaju po prvi put u obostrano inspirativnu komunikaciju koja ne počiva nužno na redukcionističkim premisama. Direktan rad s otjelovljenim iskustvom u sadašnjem trenutku postao je danas nezaobilazan dio psihoterapijskog procesa, što je rezultat dugog razvojnog puta koji su trasirale naročito tjelesno orijentirane psihoterapije. $^{12}$

Iako je seksualnost postala središtem prvog velikog psihoterapijskog narativa, Freud ju je tretirao ponajviše na simboličkoj razini; libido kao psihička energija i energetski koncepti metapsihologije ostali su apstraktni, neukorijenjeni u tijelo, bez jasne korespondencije bilo s objektivnim (tjelesnim) ili subjektivnim (fenomenološkim) pokazateljima ili s postupcima i procedurama preko kojih je moguće demonstrirati ih. Freud je, oscilirajući između nastojanja da legitimizira novu disciplinu koja počiva na istraživanju subjektivnog svijeta pacijenata i svoje duboke odanosti biologizmu i prirodoznanstvenom pogledu na svijet, ostao u okvirima kartezijanskog načina mišljenja koje je vladalo u medicini u njegovu vremenu. Dok je medicina liječila tijelo nezavisno od duše, Freud je tražio način liječenja duše nezavisno od tijela. Dok je Freud u svojem terapijskom postupku tijelo potpuno ignorirao, njegov učenik Wilhelm Reich »vraća« seksualnost u tijelo, shvativši libido kao bioenergiju čiji protok u tijelu biva blokiran uslijed dugotrajnih potiskivanja. Reich je promatrao ne samo sadržaje koji se potiskuju nego i kako tijelo učestvuje u kontroli impulsa i emocija. Dijete, pod utjecajem represivnog odgoja, zaustavlja seksualne impulse ili bijes zadržavanjem daha i mišićnim kontrakci- 
jama te ukoliko se stalno mora boriti sa svojim impulsima, utoliko rigidnosti u tijelu postaju kronične i tako nastaje mišićni oklop nad kojim osoba više nema svjesnu, voljnu kontrolu. Oklop obavlja funkciju potiskivanja i vodi k niskoj razini vitalnosti i smanjenoj sposobnosti doživljavanja osjećanja. Reichova vegetoterapija ima za cilj vratiti sposobnost prepuštanja toku životne energije i pražnjenje seksualnog nadražaja kroz nevoljne spontane konvulzije tijela, tj. orgastički refleks. ${ }^{13}$ Reichov učenik Alexander Lowen, u okviru svoje škole bioenergetike, razvija dalje tjelesnu tipologiju i niz specifičnih tjelesnih položaja i vježbi (disanja, pokreta, ekspresije) koji dovode klijenta u kontakt s vlastitim tijelom, energetskim tokom i blokadama te kataliziraju oslobađanje oklopom zarobljenih emocija. ${ }^{14}$ Iako Reich i Lowen u praksi nužno rade i sa subjektivnim, osjećajnim svijetom klijenta, oni imaju u prvom planu u vidu fizičko tijelo (Körper). Drugi Reichov učenik, Charles Kelley, osnivač radiks terapije koja pravi iskorak iz psihoanalize $\mathrm{k}$ humanističkoj psihologiji, uviđa opasnost od redukcionizma koja dolazi od fizički shvaćenog koncepta energije. Umjesto orgonske energije (Reich) tj. bioenergije (Lowen), Kelley uvodi termin radiks (lat. radix - korijen, izvor) koji je neutralno određen, kao kreativni proces koji ima subjektivne i objektivne manifestacije i predstavlja most između subjektivnog i objektivnog. ${ }^{15}$ Tok radiksa u tijelu doživljava se subjektivno kao emocija ili neki drugi oblik svjesnog iskustva, kao što su na primjer razni tjelesni osjeti, doživljaj strujanja, vibriranja, pulsiranja, a objektivno se izražava kroz izvanjski promotrive pokrete tijela. Kelley vidi svoju terapiju kao edukaciju koja za cilj ima povratiti kapacitet za osjećajnost, labavljenjem kompulzivne kontrole nad osjećanjima i straha od gubitka kontrole, koji održavaju osobu u umrtvljenom životu. Terapijski postupak procesno je orijentiran, sam proces doživljavanja inhibiranih osjećanja ljekovit je, dok konceptualizacija i kognitivna elaboracija doživljenog dolaze naknadno, utoliko ukoliko se uopće pokažu kao potrebne. Za razliku od Reicha, koji je oklop shvatio kao objektivnu strukturu koja se sastoji od kroničnih muskularnih tenzija, Kelley oklop shvaća procesno, kao stalnu aktivnost tijela koja blokira spontane ritmičke pulsacije radiksa (širenje i skupljanje) kontrapulsacijama suprotnog smjera. Nadalje, porijeklo muskularnog oklopa Kelley shvaća drugačije od Reicha. Reich je smatrao da je oklop posljedica represivnih socio-ekonomskih utjecaja iz porodice, kulture i religije. Kelley smatra da je oklop proizvod cilju usmjerenog ponašanja (k ciljevima koji nisu čisto biološki i instinktivno određeni) koje počiva na mehanizmu voljne pažnje i volj-

10

Prema Schmitzu, jedino je kategorija tjelesnosti koju je engleski neurolog Henry Head opisao kao protopatičku (difuzno, prigušeno, zračeće) i epikritičku (oštro, točkasto, jasnih obrisa) osjetljivost nezavisna od dimenzije sužavanja i širenja.

11

Vidi: Hermann Schmitz, »Phänomenologie der Leiblichkeit«, u: Hilarion G. Petzold (ur.), Leiblichkeit, Junfermann Verlag, Paderborn 1985., str. 71-104; Hermann Schmitz, Der Leib, Walter de Gruyter, Berlin, Boston 2011., str. 1-28.

12

Termin tjelesne psihoterapije (eng. body psychotherapies) usvojen je na kongresu u Lindauu 1991. godine za brojne psihotera- pijske škole koje se usmjeravaju na $\operatorname{rad} \mathrm{s}$ tijelom, počev od Reichove vegetoterapije. Danas postoji više desetina psihoterapijskih modaliteta orijentiranih na rad s tijelom.

13

Wilhelm Reich, Analiza karaktera, prevela Višnja Švab, Naprijed, Zagreb 1982.

14

Usp. Aleksander Loven [Alexander Lowen], Bioenergetika, prevela Divna Perić-Todorović, Nolit, Beograd 1984.

15

Npr. vidi: Ljiljana Klisić, Telesna psihoterapija: do orgazma i dalje, Eko-Primat-Zemun, Beograd 1995., str. 97-98. 
ne kontrole toka energije i koje je naučeno u djetinjstvu uz ulaganje napora. ${ }^{16}$ Čovjeku je prirođen konflikt osjećanja i svrhe koji u prenaglašenom vidu vodi kroničnoj napetosti i fragmentiranosti osobnosti. Utoliko je edukacija o svrsi, u smislu preispitivanja ciljeva i vrijednosti klijenta i njihovo usklađivanje s najdubljim osjećanjima, neophodan dio terapije. Kelleyjevo učenje o odnosu osjećanja i svrhe, tj. volje, izvedeno iz psihoterapijskog iskustva, neodoljivo podsjeća na Klagesova shvaćanja odnosa duše i duha iz ugla povijesti čovječanstva. Kroz rastući utjecaj, od sedamdesetih godina dvadesetog stoljeća, starih azijskih kontemplativnih, medicinskih i mentalno-higijenskih praksi (či gong, tai či, borilačke vještine, joga, akupunktura, šijacu i razni drugi oblici masaže, tradicionalna kineska medicina, tantrička i taoistička umjetnost njegovanja seksualne energije), postaje jasno da energetski koncepti novih tjelesnih terapija imaju paralelu u kineskom pojmu za životnu energiju $q i$ ili indijskom prana. Učenje o energetskoj anatomiji tijela, na kojemu počivaju ove prakse (energetski centri, kanali, meridijani) nije primarno metafizičko, kako bi moglo na prvi pogled izgledati, nego je plod jedne vrste fenomenološkog, višestoljetnog istraživanja živog tijela iz prvog lica, za razliku od anatomije zapadne medicine koja počiva na podacima trećeg lica, tj. seciranju fizičkog tijela, odnosno leševa. ${ }^{17}$ Kao što tijelo može imati dva značenja (između kojih je Schmitz izveo razlikovanje), tako i energetski koncepti u tjelesnim terapijama i azijskim sistemima mogu biti viđeni iz dva ugla, više fizikalističkog ili više fenomenološkog.

U psihoterapiji je desetljećima prisutan i jedan pristup tijelu koji potječe direktno iz fenomenologije i konzekventno je fenomenološki, koji je razvio Eugene Gendlin, američki filozof i psihoterapeut. Gendlin je, istražujući psihoterapijski proces, otkrio da se uspješan ishod terapije može najbolje predvidjeti iz načina na koji klijenti govore o svom problemu, iz kojega se može ustanoviti stupanj uključenosti doživljajne dimenzije u govor i pažnje koja se ovoj posvećuje. ${ }^{18}$ Gendlin polazi od pretpostavke da postoji vrsta tjelesne svjesnosti koja igra značajnu ulogu u svakodnevnom životu i mišljenju, a koja je u toj mjeri bila zapostavljena u svakomu teoretiziranju o ljudskom duhu da za nju ne postoji riječ. Tako on uvodi termin felt sense koji se obično ne prevodi. O felt sense-u može se govoriti kao o auri (ukusu, tonu) koji okružuje neki predmet, problem, emociju, misao ili interpersonalnu situaciju. Felt sense nije emocija - emocije su jasne, izoštrene i mogu se imenovati, a felt sense je nejasan, kompleksan doživljaj i gotovo nikada se isprva ne može opisati riječima. Ispoljava se kao globalan, kao holistički, obično ne vrlo oštro i ne kao specifično određen tjelesni osjećaj. ${ }^{19}$ Ukoliko mu se pokloni posebna vrsta pažnje (s otvorenim, radoznalim stavom), utoliko se felt sense relativno brzo (za oko pola minute) otvara k verbalnoj artikulaciji, makar u aproksimativnom i metaforičkom smislu. U psihoterapijskoj situaciji je, dakle, pored kognitivno-narativnog rada ili rada s emocijama, kao u prvoj generaciji tjelesnih terapija, prisutan ovaj suptilni, neverbalni doživljaj (kako klijent »cijelim tijelom « opaža neku problematičnu situaciju, odnos, događaj...) u kojemu je, prema Gendlinu, zapravo ključ promjene. Gendlin otkriva nešto interesantno: sam kontakt sfelt sense, ukoliko mu se priđe s određenom vrstom pažnje, utoliko čini na njemu promjenu. Promjenu je moguće osjetiti kao tjelesnu promjenu, manje ili više lokaliziranu, vrstu pokreta, pomaka, osjećaj da neka tenzija ili grč, »zgusnuće« (»zakočenost«) popuštaju, omekšavaju, što je praćeno olakšanjem. Ovaj je prelaz Gendlin nazvao felt shift (doživljeni pomak).

Nove terapije orijentirane na tijelo (npr. Peter Levine - somatic experiencing; Pet Ogden - sensomotor psychotherapy) razvile su se naročito u psihoterapiji posttraumatskog sindroma, prilikom koje je rad s tijelom postao nezao- 
bilazan. ${ }^{20}$ Instinktivna reakcija zamrzavanja ${ }^{21}$ dovodi do osjećanja tuposti i neprisutnosti u tijelu, uslijed straha od ponovnog preplavljivanja neprijatnim senzacijama. Razgovor o traumi (top down pristup u suvremenoj terminologiji $)^{22}$ ne čini to da doživljajno tijelo za klijenta postane ponovo sigurno mjesto, a može i prizvati u sjećanje traumatski doživljaj na nekontroliran način, što samo doprinosi retraumatizaciji. Put obnavljanja zamrznutih energetskih tokova u postepenom je oslobađanju, reintegraciji i ovladavanju neprijatnim osjećanjima i senzacijama kroz direktan rad s tijelom, disanjem i pokretom u sadašnjem trenutku (bottom up pristup). Ovaj postupak primarno je fenomenološki, zasnovan na mindfulness ${ }^{23}$ postupcima koji danas imaju široku primjenu u psihoterapiji jer omogućavaju praćenje, iz trenutka u trenutak, onoga što se zbiva u vlastitom tijelu. Tako se »prozor« tolerancije za doživljavanje, koji je kod traumatiziranih veoma sužen, postepeno proširuje, pri

16

Vidi: Charles Kelley, »What is the Matter with Man? The Origin of Muscular Armor«, Chuck Kelley's Radix Journal 2 (1-2/1980). Dostupno na: http://www.kelley-radix.org/ downloads/what is the matter with man. pdf (pristupljeno 22. 9. 2017.).

17

Tako, na primjer, stimulacija određenih točaka na stopalima koja pripadaju »meridijanu bubrega« može dovesti do senzacije topline $u$ predjelu bubrega, isto kao i prakticiranje pojedinih či gong pokreta. Energetska anatomija, opis fizičkih organa, kao i čitav medicinski sistem počivaju na subjektivnim podacima (tjelesne senzacije - toplo, hladno, bol, pritisak, pravac strujanja energije, boje, ukusi, zvuci).

18

Eugene Gendlin, Focusing, Otto Müller Verlag, Salzburg 1981., str 15-18.

19

Mislimo da je pojam felt sense veoma blizu Jamesovu pojmu »rubova svijesti« (fringe) koji »lebde« oko nekog eksplicitnog sadržaja tj. supstantivnog stanja. James je ove prolazne $\mathrm{i}$ teško uhvatljive fenomene registrirao $u$ toku svijesti i dao im ime, a Gendlin nastoji pažljivim izborom pitanja, u čemu se sastoji njegova metoda fokusiranja, usmjeriti pažnju klijenta na njih. Gendlin tijelo u psihoterapiji tretira konsekventno fenomenološki, kao Leib, u smislu Schmitzove distinkcije Leib nasuprot Körper.

20

Usp. Pat Ogden i dr., Trauma and the Body: A Sensorimotor Approach to Psychotherapy, W. W. Norton, New York 2006.

21

U studijama iz engleskog govornog područja često se govori o $3 F$ - fight, flight, freeze (boriti se, bježati, smrznuti se) - kao o instinktivnim, biološki programiranim reakcijama na opasnost. Treća je, prije svega, karakteristična za traumatizaciju; ukoliko se zamrznutost i »paraliza« poslije traumatske situacije ne stresu iz tijela (kao što to čine životinje u prirodnim uvjetima života), one dovode do posttraumatskog poremećaja koji može trajati godinama. Vidi: Peter A. Levine, Healing Trauma: A Pioneering Program for Restoring the Wisdom of Your Body, Sounds True 2008.

22

Top down pristup pokušava regulirati procese na afektivnoj i senzomotornoj razini preko kognitivne - doživljaj se mijenja uz pomoć koherentnog narativa i razumijevanja. Bottom up pristup polazi od tjelesnih osjećaja i pokreta, nastojeći promjenom u doživljajnoj sferi postići promjenu u razumijevanju, samoregulaciji i procesiranju traumatskih sjećanja. Dok su starije psihoterapije (psihoanalitičke orijentacije i kognitivne terapije) prvenstveno koristile top down pristup, suvremene tjelesne psihoterapije kombiniraju oba pristupa.

23

Mindfulness postupci, porijeklom iz budizma, našle su veoma široku primjenu u psihoterapiji 21. stoljeća. Njihova sućina je, ukratko, u pažljivom otvorenom promatranju sadašnjeg iskustva koje je u stalnom procesu promjene, iz trenutka na trenutak, s neprocjenjujućim, otvorenim stavom. Mindfulness meditacija, kao solitarna sjedeća praksa, pokazala se kontraindikacijskom kod traumatiziranih. Ovaj način prakticiranja sabranosti koji dovodi do relaksacije i smanjenja svakodnevnih mentalnih aktivnosti, prilika je za to da preplavljujuća traumatska sjećanja i senzacije povezane s traumom ponovo dođu u svijest, a to je upravo ono čega se traumatizirani najviše boje. Prakticiranje sabranosti u interpersonalnom okviru (Ogden uvodi termin embedded relational mindfulness) i u okviru joga vježbi pokazalo se znatno primjerenijim kod ove populacije. Npr. vidi: Bessel van der Kolk, The Body Keeps the Score: Brain, Mind, and Body in the Healing of Trauma, Penguin Books, New York 2015. 
čemu je njihova potreba za sigurnošću istovremeno uvažena. ${ }^{24} \mathrm{~S}$ obzirom na to da je trauma pohranjena na somatskoj i senzomotornoj razini, čisto verbalno-kognitivno-narativni pristupi (top down) uspijevali su, u najboljem slučaju, poboljšati sposobnost izlaženja na kraj s traumatizacijom i adaptivnije ponašanje u svakodnevnom životu. U kombinaciji s bottom up postupcima (direktan »mikroskopski« rad s tijelom i tjelesnim doživljavanjem, umjesto govora o doživljaju) rezultat je dalekosežniji - obnova vitalnosti, životne radosti, »resetiranje« traumom dereguliranog nervnog sistema. Terapeut pitanjima potiče proces točnog promatranja svega što se može osjetiti u tijelu i pomaže klijentu pronaći riječi kojima će opisati svoje iskustvo. Schmitzov alfabet tjelesnosti ovdje može biti od pomoći. Dok su, međutim, Schmitzovi opisi raznih tjelesnih stanja neutralni, opis se u psihoterapiji rađa u kontekstu dinamičkog dijaloga terapeuta i klijenta, generalno usmjerenog od problema $\mathrm{k}$ rješenju, od mučnog i neprijatnog stanja, zbog koga je klijent na terapiji, $\mathrm{k}$ boljem. U psihoterapijskom kontekstu, problem (u smislu onoga na čemu rade terapeut i klijent) se uglavnom doživljava kao sužavanje, često kao zaglavljenost, dok je rješenje praćeno doživljajem širenja, otvaranja novog prostora. Samo posvećivanje neposrednim tjelesnim osjećajima i osjećanjima povezanim s problemom ljekovito je i otvarajuće jer dovodi do promjene (Gendlinov felt shift) u pravcu širenja.

U suvremenom psihoterapijskom pristupu tijelu, ono je mnogo više od rezervoara potisnutih emocija. Tijelo je nosilac sjećanja, znanja, »unutrašnje mudrosti« koja nadilazi verbalno i izrecivo, a može poslužiti kao putokaz k terapijskim rješenjima. Tijelo je i poput mjernog instrumenta pomoću kojega imamo direktan intuitivni uvid u kompleksne situacije, npr. doživljavamo li situaciju kao »laku« ili »tešku«, »otvarajuću« ili »blokirajuću«, krećemo li se $» k \ll$ nečemu i »od《 nečega. Klijenti su u stanju dati brze i precizne odgovore na ovakva pitanja, a oni postaju značajna povratna informacija u radu.

Tematizacija tjelesnosti i u fenomenologiji i u psihoterapiji ima korijen u impulsu detabuiziranja tema za koje predugo nije bilo mjesta ni u filozofiji ni u znanosti. Nietzsche, Klages i Schmitz, svaki na svoj način, vraćaju se u daleku prošlost, tražeći korijen tendencije da tjelesnost, iako jedna od najvažnijih činjenica čovjekovog života, ima tako marginalan teorijski status. Psihoterapeuti razvijaju dalje svijest o tome da su dobar kontakt s vlastitim tijelom, spontanost te kapacitet za osjećajnost i doživljavanje zadovoljstva važne determinante mentalnog zdravlja. Izostavljanje iz teorije neopredmećenih, nereprezentiranih segmenata iskustva, koji su uglavnom fluidni, tako da je potreban izvjestan kapacitet pažnje da bismo ih primijetili, neizrecivi ili na granici verbalizacije $\mathrm{i}$ ispod praga pojmovne osviještenosti, ostavlja nas $\mathrm{s}$ modelom duha u kojemu su prenaglašeni racionalni, komputacijski procesi, kakav nam danas nude kognitivna psihologija i kognitivna psihoterapija. Psihoanalitički koncept nesvjesnog iz ugla tjelesno-orijentiranih terapija može se vidjeti kao proizvod introjekcionizma. Umjesto unutrašnjeg, skrivenog, misterioznog dijela psihe koji sprema potisnute sadržaje, tjelesno i fenomenološki orijentirani pristupi vide nesvjesno u tijelu i iščitavaju ga kroz tjelesno u terapijskom procesu. Njima je utjecaj ovih još neartikuliranih, fluidnih dijelova iskustva na mišljenje, donošenje odluka i psihoterapijsku promjenu već dugo poznat. Danas potvrda za to dolazi i iz neuroznanosti. Neurobio$\log$ Antonio Damasio razvio je, na osnovu proučavanja neuroloških slučajeva (oštećenja ventromedijalnog prefrontalnog korteksa $\mathrm{s}$ istovremeno potpuno očuvanim kognitivnim sposobnostima), teoriju o somatskim markerima koji predstavljaju tjelesni signalni sistem u kojemu je pohranjeno emocionalno sjećanje na iskustva. Somatski markeri na esencijalan način pomažu u sva- 
kodnevnom donošenju odluka i promišljanju i vrednovanju alternativa. Tijelo, tjelesni osjeti i osjećanja osiguravaju direktno intuitivno znanje o situaciji bez koje je čisto racionalno rezoniranje nedostatno za normalno ponašanje, što je evidentno kod ljudi s gore spomenutim moždanim oštećenjem. ${ }^{25}$

Čisto verbalno-narativne psihoterapije mogu čak probuditi, u našoj kulturi naglašenu, podvojenost duha i tijela, na koju su ukazivali Nietzsche, Klages i Schmitz. Konačno, psihoterapija radi na restauraciji povjerenja u vlastito otjelovljeno iskustvo, čime bar dijelom ispravlja posljedice postvarenja i obezvređivanja subjektivnog, osjećajnog svijeta u današnjem društvu.

\title{
Izabela Huber
}

\section{Phenomenology of Body and Body Psychotherapies}

\begin{abstract}
After Nietzsche and Klages prepared a ground for the body to become the subject of philosophical investigations understood differently than within the Cartesian system or natural sciences, Schmitz developed the first systematic phenomenological approach to it. Schmitz takes the subject up from the radical and consistent phenomenological definition of body (Leib in contrast to Körper), and devises theoretical framework and vocabulary which enables talking about an entire span of states experienced through body. In psychotherapy, body was thematised firstly in early body psychotherapies that had their root in psychoanalysis (Reich, Lowen, Kelley). In these, the understanding of body as phyisical body (Körper) is predominant. Purely phenomenological approach to body in psychotherapy (in the sense of Schmitz's Leib) was developed by Gendlin. Contemporary body-oriented psychotherapies (Levine, Ogdne, van der Kolk) were most notably developed in posttraumatic syndrome therapies, and they integrate phenomenological research on body with cognitive-narrative approaches and new neurobiological discoveries. Each in its own way, both the phenomenology of body and body psychotherapies attempt to balance the hypertrophy of rational, cognitive and spiritual within the culture, shifting the focus to the field of corporeality, on the intangible, fluid, almost ineffable parts of experience, for centuries marginalized in philosophy and science despite the fact that they play an important role in life-world (Lebenswelt).
\end{abstract}

\section{Key words}

phenomenology, body, body psychotherapies, Hermann Schmitz, Friedrich Nietzsche, Ludwig Klages

Traumatski doživljaj spada u stanja koja Schmitz opisuje kao elementarnu tjelesnu pogođenost (poput straha, užasa, panike, bola i snažnog stida), koje karakterizira iznenadno sužavanje i primitivna sadašnjost, a posttraumatski sindrom može se vidjeti kao prolongirano bivanje u stanjima u kojima prevladavaju suženost i kontrakcija.
25

Vidi: Antonio Damasio, Descartes' Error: Emotion, Reason, and the Human Brain, Penguin Books, London 2005. 
